\title{
Ovarian function in the ewe after active immunization against testosterone
}

\author{
R. J. Scaramuzzi, D. T. Baird, N. D. Martensz*, K. E. Turnbull and \\ P. F. A. Van Look $†$ \\ C.S.I.R.O., Division of Animal Production, P.O. Box 239, Blacktown, \\ New South Wales 2148, Australia, and \\ M.R.C. Unit of Reproductive Biology, 37 Chalmers Street, Edinburgh EH3 9EW, U.K.
}

\begin{abstract}
Summary. The secretion rates of testosterone measured during the last half of the oestrous cycle in 2 Merino crossbred ewes with utero-ovarian autotransplants were $1.95 \pm 0.34 \mathrm{ng} / \mathrm{min}$ and $2.48 \pm 0.63 \mathrm{ng} / \mathrm{min}$. The secretion rate of testosterone was not correlated with the secretion rate of oestradiol or androstenedione in either ewe.

Welsh Mountain ewes were actively immunized against testosterone-3-(Ocarboxymethyl)-oxime-bovine serum albumin (testosterone-3-BSA) or BSA alone (controls). Immunization against testosterone-3-BSA (5 ewes) resulted in anovulation ( 2 ewes) and the disruption of oestrous cycles and irregular ovulations (2 ewes). The ovaries showed morphological and endocrinological evidence of over-stimulation. Numerous large non-atretic follicles were present and in those ewes still ovulating the numbers of corpora lutea (ovulation rate) were increased. The concentrations of androstenedione and of oestradiol in the ovarian venous plasma were also markedly increased when compared to those in control ewes. The plasma binding capacity for steroids and the jugular venous concentrations of steroids were higher in immunized ewes. The binding capacity of follicular fluid for testosterone was similar to that of jugular venous plasma from the same ewe.

These results show that immunization against testosterone-3-BSA leads to a disruption of ovarian cycles and ovarian over-stimulation.
\end{abstract}

\section{Introduction}

Testosterone can be secreted into the ovarian vein by sheep ovaries in vivo (Baird, Goding, Ichikawa \& McCracken, 1968) and by ovarian follicles maintained in organ culture (Seamark, Moor \& McIntosh, 1974). The ability of exogenous testosterone to induce oestrus (Lindsay \& Robinson, 1961), LH release (Pant, 1977; Clarke \& Scaramuzzi, 1978) and ovulation (Radford \& Wallace, 1971) in ewes suggests that secreted testosterone may have some biological function. It has also been suggested that testosterone acts locally to induce ovulation in immature rats (Mori, Suzuki, Nishimura \& Kambegawa, 1977) and follicular atresia in the adult rat (Louvet, Harman, Schreiber \& Ross, 1975; Baird, 1977). The involvement of testosterone in sheep reproduction was studied in the present experiments.

* Present address: Department of Anatomy, University of Cambridge, Cambridge CB2 3DY, U.K.

† Present address: Vrouwenkliniek, Academisch Ziekenhuis Leiden, Rijnsburgerweg 10, Leiden, The Netherlands. 


\section{Materials and Methods}

\section{Experiment 1}

Two Merino crossbred ewes with utero-ovarian autotransplants (Baird, Land, Scaramuzzi \& Wheeler, 1976a) were cannulated and bled every $6 \mathrm{~h}$ from Day 12 of the oestrous cycle (Baird, Land, Scaramuzzi \& Wheeler, 1976b). The concentration of testosterone in the blood from the utero-ovarian vein was determined by radioimmunoassay (Corker \& Davidson, 1978) and the secretion rate of testosterone was calculated (Baird et al., 1976b). The secretion rates of oestradiol-17 $\beta$, androstenedione, progesterone and the peripheral concentrations of $\mathrm{LH}$ have already been published (see Fig. 3 of Baird et al., 1976b).

\section{Experiment 2}

Immunization. Five Welsh Mountain ewes were immunized with $2.0 \mathrm{mg}$ testosterone3-(O-carboxymethyl)-oxime-bovine serum albumin (testosterone-3-BSA) in Freund's complete adjuvant in November 1974 (Scaramuzzi, Corker, Young \& Baird, 1975). Booster immunizations were given in February $1975(2.0 \mathrm{mg})$ and August $1975(0.7 \mathrm{mg})$. A control group of 5 ewes were immunized against BSA at the same times.

Sample collection. During September 1975 oestrus and ovulation were synchronized in the 10 ewes by intravaginal progestagen pessaries (Synchromate: G. D. Searle and Co., High Wycombe, Bucks). Following removal of the pessaries all 4 surviving control ewes and 1 immunized ewe experienced regular oestrous cycles lasting 16-19 days. The other ewes immunized against testosterone-3-BSA remained anoestrous. Laparotomies were performed on Days $9-10$ of the third oestrous cycle after synchronization or an equivalent day in the anoestrous animals (i.e. 47 days after removal of the pessaries). Ovarian venous blood (25 $\mathrm{ml})$ was collected bilaterally either by cannulation of the ovarian vein (Baird \& Scaramuzzi, 1976) or by aspiration using a syringe and 21-gauge needle (Scaramuzzi \& Land, 1978). A sample of jugular venous blood was collected at the same time. Follicular fluid was also collected from the large follicles ( $>5 \mathrm{~mm}$ diameter) using a syringe and 23-gauge needle. A second laparotomy was carried out on all ewes 6 weeks later and 12 days after the end of a course of exogenous progesterone injections (10 mg/day for 12 days). Samples of ovarian venous blood, jugular venous blood and follicular fluid were collected as above. At the second laparotomy the ovaries were removed.

Histology. Corpora lutea were dissected free from the ovaries, weighed and placed in aqueous Bouin's fixative. The remainder of the ovary was also weighed and placed in aqueous Bouin's fixative.

The ovaries of 3 control (ovulating regularly) and 3 immunized ewes ( 1 ovulating regularly, 1 ovulating irregularly and 1 anovulatory) were serially sectioned at $15 \mu \mathrm{m}$ and stained with haematoxylin and eosin. Graafian follicles were first located with a projection microscope and then examined (Turnbull, Braden \& Mattner, 1977). Follicle diameter, follicle volume and mitotic index of the granulosa cell layer were determined as described by Turnbull et al. (1977) for all follicles $0.3-5.0 \mathrm{~mm}$ diameter and for a representative random sample of smaller follicles (Turnbull et al., 1977). Precise measurements on larger follicles were not possible because of the prior removal of follicular fluid.

Follicles were segregated into 8 classes on the basis of doubling of the granulosa volume and began with an arbitrary volume of $16 \times 10^{6} \mu \mathrm{m}^{3}$ (i.e. approximately $0.32 \mathrm{~mm}$ diameter). The mean mitotic index of the granulosa cell layer and the corresponding mean diameter for follicles in each class were determined and used to construct growth curves. Follicles were classified as non-atretic or early atretic depending upon the absence or presence of atretic bodies within the granulosa respectively (Turnbull et al., 1977). Atretic follicles in which the cellular disintegration of the granulosa was either widespread or complete were excluded from the study. 
Assay procedures

Blood samples were heparinized and the plasma was removed after centrifugation at $4^{\circ} \mathrm{C}$. Follicular fluid and plasma were stored at $-20^{\circ} \mathrm{C}$ until assayed. Following acidification with $1 \mathrm{~N}-\mathrm{HCl}$ the concentrations of steroids were measured by the radioimmunoassays described in detail elsewhere; oestrone, oestradiol-17 $\beta$ and androstenedione (Baird, Burger, Heavon-Jones \& Scaramuzzi, 1974; Baird, Swanston \& Scaramuzzi, 1976c); testosterone (Corker \& Davidson, 1978); and progesterone (Scaramuzzi et al., 1975). For the assay of these steroids in follicular fluid the same antisera were used but the methods of extraction and separation were as described by McNatty et al. (1976) for follicular fluid.

The characteristics of the assays used in the present analyses are:

$\begin{array}{lccc} & \text { Antiserum } & \begin{array}{c}\text { Limit of } \\ \text { precision }(\%)\end{array} & \begin{array}{c}\text { Limsitivity } \\ (\mathrm{pg} / \mathrm{ml})\end{array} \\ \text { Oestrone } & 029-14 & 12 & 10 \\ \text { Oestradiol-17 } & - & 9 \cdot 5 & 10 \\ \text { Androstenedione } & \text { Shopman } & 15 & 150 \\ \text { Testosterone } & \text { E 01 } & 11.5 & 10 \\ \text { Progesterone } & 91920 / 9 & 13 & 200\end{array}$

The antiserum used for the assay of the oestradiol fraction was a specific antiserum raised against the 17ß-oestradiol-6(O-carboxymethyl)-oxime-BSA (Dean, Exley \& Johnson, 1971; Van Look, Hunter, Corker \& Baird, 1977).

The binding of exogenous steroids by non-acidified jugular venous plasma was measured by a dextran-charcoal radioassay (Scaramuzzi et al., 1975).

\section{Statistical procedures}

The concentrations of steroids in ovarian venous plasma were analysed by a split-plot analysis of variance. The main-plot treatment was immunization and the sub-plots were formed by the side from which the ovarian venous blood was collected. Before statistical analysis all steroid concentrations were transformed to logarithms to overcome heterogeneity of variance. Data on ovulation rates and follicle numbers were analysed using Fisher's exact test and Wilcoxon's Rank Sum test respectively. All other data were analysed by Student's $t$ test.

\section{Results}

Experiment 1: secretion rate of testosterone during the oestrous cycle

The pattern of secretion of testosterone during the second half of the oestrous cycle is illustrated for both ewes (Text-fig. 1). The mean \pm s.e.m. secretion rate was $1.95 \pm 0.34 \mathrm{ng} / \mathrm{min}$ $(n=33)$ for Ewe 16 (Text-fig. 1a) and $2.48 \pm 0.63 \mathrm{ng} / \mathrm{min}(n=25)$ for Ewe 30 (Text-fig. 1b). There did not appear to be any temporal relationship between the secretion of testosterone and any of the other hormones measured (Text-fig. 1). The secretion rate of testosterone was not significantly correlated with the secretion rate of oestradiol $(r=0.08$ and 0.26 for Ewes 16 and 30 respectively) or of androstenedione ( $r=0.11$ and 0.35 for Ewes 16 and 30 respectively).

\section{Experiment 2: immunization against testosterone-3-BSA}

Steroids. After immunization against testosterone-3-BSA 4 ewes became anoestrous within 1 month of immunization and remained so until ovariectomy 13 months later although at 


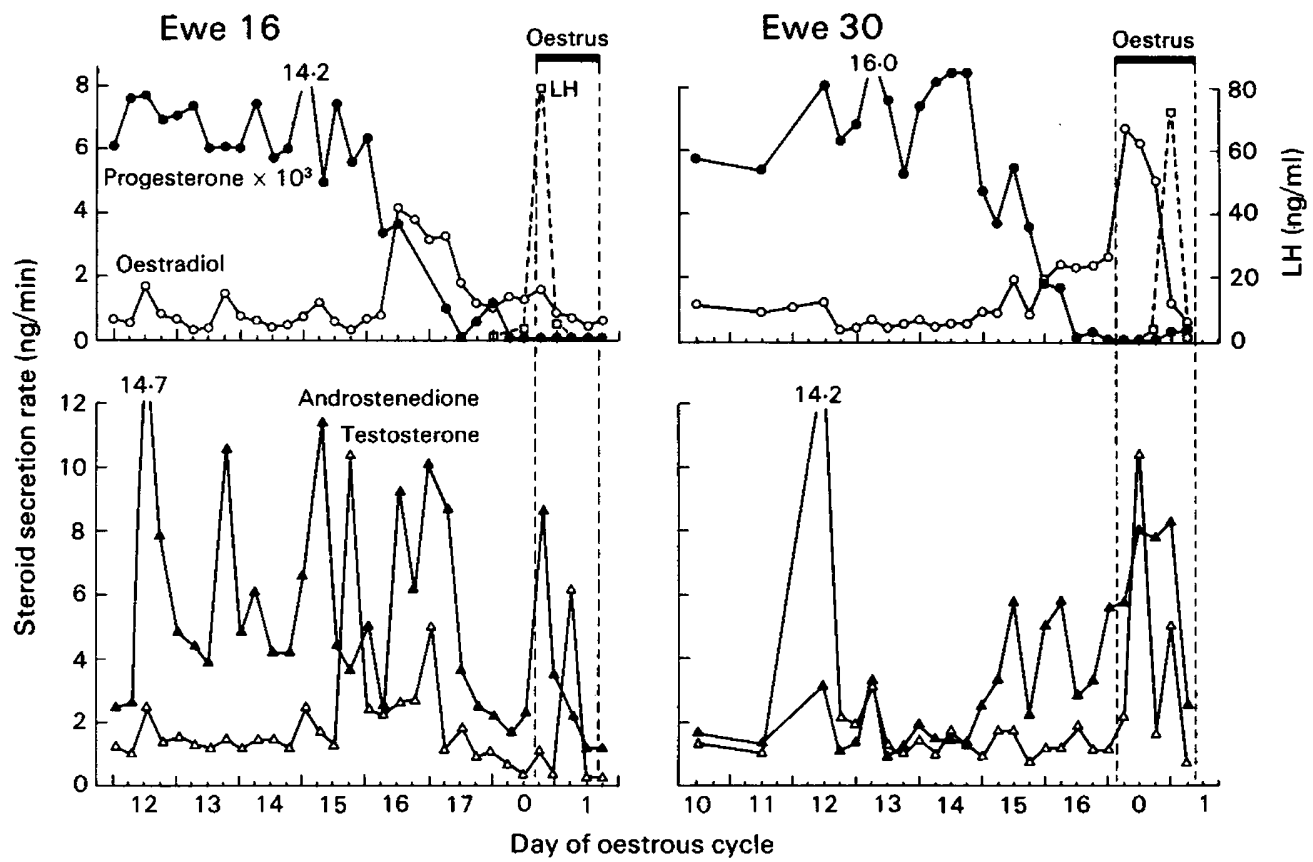

Text-fig. 1. The secretion rates of progesterone $(\boldsymbol{O})$, oestradiol $(\mathbf{O})$, androstenedione $(\Delta)$ and testosterone $(\triangle)$ and the peripheral concentration of LH $(\square)$ during the last half of the oestrous cycle in 2 Merino cross-bred ewes with utero-ovarian-cervical autotransplants (Exp. 1).

laparotomy the presence of corpora albicantia in 2 of these animals suggested the occurrence of sporadic silent ovulations. The remaining immunized ewe and the 4 surviving control ewes continued to have regular oestrous cycles except for the period of the normal seasonal anoestrus. At laparotomy 3 immunized ewes had corpora lutea or corpora albicantia present in their ovaries although only 1 of these 3 ewes was undergoing regular oestrous cycles (Table 1). The ovaries of the immunized ewes were heavier than those of the control animals and the ovaries of the anoestrous animals were cystic in appearance. These ovaries contained numerous follicles up to $29 \mathrm{~mm}$ in diameter. Some of the follicles were thin-walled and fluid-filled while others had asymmetrically thickened walls which appeared partly luteinized.

Table 1. The number of ewes showing oestrus and ovulation and the mean ( \pm s.e.m.) for ovulation rate, follicle number and weights of corpora lutea and ovaries during the breeding season of Welsh Mountain ewes immunized against testosterone-3-BSA or BSA (controls)

\begin{tabular}{lcc}
\hline & \multicolumn{2}{c}{ Immunized against: } \\
\cline { 2 - 3 } & Testosterone-3-BSA & BSA \\
\hline No. of ewes & 5 & 4 \\
No. of ewes showing regular oestrus & 1 & 4 \\
No. of ewes ovulating (CL or CA present at either laparotomy) & 3 & 4 \\
Ovulation rate (of ewes ovulating) & $2 \cdot 8 \pm 0 \cdot 25^{*}$ & $1.5 \pm 0.2$ \\
Wt of CL (g) & $0.49 \pm 0.01$ & $0.50 \pm 0.05$ \\
Wt of ovaries including CL (g) & $5.62 \pm 2 \cdot 15^{*}$ & $1.19 \pm 0 \cdot 18$ \\
No. of surface follicles ( $>3$ mm diameter) per ovary & $6.7 \pm 0.9^{* *}$ & $1.2 \pm 0.3$ \\
\hline
\end{tabular}

Significantly different from values for control ewes: ${ }^{*} P<0.05,{ }^{* *} P<0.01$. 
As prior analysis had shown no differences between the concentrations of steroids in the ovarian venous and jugular venous plasma and follicular fluid obtained at each laparotomy, the data were pooled for final analysis and presentation (Tables 2 and 3). Immunization against testosterone-3-BSA appeared to produce an increase in the secretory activity of the ovary. The net secretion (as judged by the difference in concentration of steroid between ovarian venous plasma and jugular venous plasma) of oestradiol and androstenedione was greatly increased while that of testosterone and oestrone was increased to a lesser degree. The jugular venous concentration of all steroids was increased in testosterone-immunized ewes.

The concentration of steroids in follicular fluid varied greatly from follicle to follicle and the follicles were classified as active or inactive on the basis of the concentration of oestradiol-17 $\beta$ in follicular fluid (Scaramuzzi, Baird, Clarke, Martensz \& Van Look, 1980). Active follicles were

Table 2. The mean ( \pm s.e.m.) concentration of steroids in ovarian venous and jugular venous plasma during the breeding season of Welsh Mountain sheep actively immunized against testosterone-3-BSA or BSA (control)

\begin{tabular}{|c|c|c|c|}
\hline \multirow[b]{2}{*}{$\cdots$} & \multirow[b]{2}{*}{ Vein } & \multicolumn{2}{|c|}{ Immunized against: } \\
\hline & & $\begin{array}{c}\text { Testosterone-3-BSA } \\
(\mathrm{N}=5)\end{array}$ & $\begin{array}{c}\mathrm{BSA} \\
(\mathrm{N}=4)\end{array}$ \\
\hline Oestrone (pg/ml) & $\begin{array}{l}\text { Ovarian } \\
\text { Jugular }\end{array}$ & $\begin{array}{r}336 \pm 140 \\
66 \pm 19^{* * *}\end{array}$ & $\begin{array}{c}109 \pm 18 \\
19 \pm 2\end{array}$ \\
\hline Oestradiol-17$\beta(\mathrm{pg} / \mathrm{ml})$ & $\begin{array}{l}\text { Ovarian } \\
\text { Jugular }\end{array}$ & $\begin{aligned} 2028 & \pm 585^{* * *} \\
105 & \pm 26^{* *}\end{aligned}$ & $\begin{array}{l}59 \pm 13 \\
33 \pm 4\end{array}$ \\
\hline Androstenedione $(\mathrm{pg} / \mathrm{ml})$ & $\begin{array}{l}\text { Ovarian } \\
\text { Jugular }\end{array}$ & $\begin{array}{l}70734 \pm 14355^{* * *} \\
45908 \pm 18432^{* * *}\end{array}$ & $\begin{array}{l}339 \pm 62 \\
125 \pm 71\end{array}$ \\
\hline Testosterone $(\mathrm{pg} / \mathrm{ml})$ & $\begin{array}{l}\text { Ovarian } \\
\text { Jugular }\end{array}$ & $\begin{array}{l}8439 \pm 2044^{* * *} \\
7364 \pm 2722^{* * *}\end{array}$ & $\begin{array}{r}217 \pm 54 \\
44 \pm 15\end{array}$ \\
\hline Progesterone (ng/ml) & $\begin{array}{l}\text { Ovarian } \dagger \\
\text { Ovarian } \ddagger \\
\text { Jugular }\end{array}$ & $\begin{array}{c}1187 \pm 891 \\
243 \pm 78 \\
5 \cdot 2 \pm 2 \cdot 1\end{array}$ & $\begin{array}{l}582 \pm 138 \\
3.9 \pm 8.1 \\
3.1 \pm 0.2\end{array}$ \\
\hline
\end{tabular}

Values (for $\log _{10}$ transformed data) significantly different from those for control ewes:

** $P<0.01,{ }^{* * *} P<0.001$.

$\dagger$ Vein draining ovaries containing active CL.

$\mp$ Vein draining ovaries not containing $\mathrm{CL}$ or $\mathrm{CA}$.

Table 3. The mean ( \pm s.e.m.) for follicular diameter and for the concentrations of steroids in follicular fluid taken during the breeding season from Welsh Mountain ewes immunized against testosterone-3BSA

\begin{tabular}{lcc}
\hline & \multicolumn{2}{c}{ Follicle classification } \\
\cline { 2 - 3 } & $\begin{array}{c}\text { Active } \\
(n=24)\end{array}$ & $\begin{array}{c}\text { Inactive } \\
(n=10)\end{array}$ \\
\hline Diameter of follicle $(\mathrm{mm})$ & $11 \cdot 8 \pm 1 \cdot 2$ & $19.9 \pm 1 \cdot 6^{* *}$ \\
Oestradiol-17 $\beta(\mathrm{ng} / \mathrm{ml})$ & $358 \cdot 6 \pm 58 \cdot 1$ & $15 \cdot 8 \pm 6 \cdot 3^{* * *}$ \\
Oestrone $(\mathrm{ng} / \mathrm{ml})$ & $84.9 \pm 15 \cdot 5$ & $21 \cdot 5 \pm 8 \cdot 0^{* *}$ \\
Androstenedione $(\mathrm{ng} / \mathrm{ml})$ & $855 \cdot 0 \pm 208 \cdot 6$ & $242 \cdot 0 \pm 110 \cdot 9^{*}$ \\
Testosterone $(\mathrm{ng} / \mathrm{ml})$ & $40 \cdot 7 \pm 6 \cdot 3$ & $12 \cdot 9 \pm 3 \cdot 7^{* *}$ \\
Progesterone $(\mathrm{ng} / \mathrm{ml})$ & $317.3 \pm 43.6$ & $1125 \cdot 2 \pm 217 \cdot 1^{* * *}$ \\
\hline
\end{tabular}

Significantly different from values for active follicles: ${ }^{*} P<0.05$, ${ }^{* *} P<0.01,{ }^{* * *} P<0.001$ (probabilities for all values except follicle diameter apply to $\log _{10}$ transformed data). 
smaller than inactive follicles and contained greater concentrations of oestradiol-17 $\beta$, oestrone, androstenedione and testosterone but lower concentrations of progesterone (Table 3). Follicles from control (BSA-immunized) ewes were too small ( $<5 \mathrm{~mm}$ diameter) to provide follicular fluid for steroid analyses.

Histology. The pattern of follicular growth and atresia in follicles $0.3-5.0 \mathrm{~mm}$ diameter was similar for the BSA- and testosterone-immunized ewes (Table 4; Text-fig. 2). However, the mitotic index of the granulosa in follicles $1.0-2.5 \mathrm{~mm}$ diameter was substantially higher in the testosterone-immunized ewes (Text-fig. 2). This trend was reversed in larger follicles $(2 \cdot 5-5 \cdot 0$ $\mathrm{mm}$ diameter). There were no significant differences in the total number of follicles, or the number of atretic follicles $0.3-5.0 \mathrm{~mm}$ diameter (Table 4). However, the number of non-atretic follicles $3 \cdot 0-5 \cdot 0 \mathrm{~mm}$ diameter was significantly higher in testosterone-immunized ewes $(P<$ $0.01)$.

Table 4. The number of atretic and non-atretic follicles in the ovaries of Welsh Mountain ewes immunized against testosterone-3-BSA or BSA (controls)

\begin{tabular}{|c|c|c|c|c|c|c|c|}
\hline & \multirow{3}{*}{$\begin{array}{c}\text { Follicle } \\
\text { diam. (mm) }\end{array}$} & \multicolumn{6}{|c|}{ Immunized against: } \\
\hline & & \multicolumn{3}{|c|}{ Testosterone-3-BSA } & \multicolumn{3}{|c|}{ BSA } \\
\hline & & Ewe 443 & Ewe 397 & Ewe 550 & Ewe A & Ewe B & Ewe C \\
\hline No. of $C L$ or $C A$ & & 4 & 2 & 0 & 1 & 1 & 1 \\
\hline Reciprocal antibody titre & & 15000 & 21000 & 25000 & 1 & 1 & 1 \\
\hline $\begin{array}{l}\text { No. of atretic follicles } \\
\text { (all sizes) }\end{array}$ & & 13 & 4 & 9 & 25 & 10 & 9 \\
\hline $\begin{array}{l}\text { No. of normal follicles } \\
\text { (non-atretic) }\end{array}$ & $\begin{array}{c}0 \cdot 3-1 \cdot 0 \\
1-3 \\
3-5 \\
5-10 \\
>10 \\
\text { Total }\end{array}$ & $\begin{array}{r}16 \\
3 \\
3 \\
0 \\
0 \\
21\end{array}$ & $\begin{array}{r}28 \\
7 \\
6 \\
2 \\
1 \\
44\end{array}$ & $\begin{array}{r}21 \\
7 \\
6 \\
2 \\
3 \\
39\end{array}$ & $\begin{array}{r}54 \\
6 \\
1 \\
0 \\
0 \\
61\end{array}$ & $\begin{array}{r}20 \\
9 \\
2 \\
0 \\
0 \\
31\end{array}$ & $\begin{array}{c}20 \\
8 \\
1 \\
0 \\
0 \\
29\end{array}$ \\
\hline $\begin{array}{l}\text { No. of abnormal follicles } \\
\text { (non-atretic) }\end{array}$ & $\begin{array}{l}3-5 \\
5-10 \\
>10\end{array}$ & $\begin{array}{l}0 \\
0 \\
0\end{array}$ & $\begin{array}{l}0 \\
0 \\
0\end{array}$ & $\begin{array}{l}3 \\
1 \\
2\end{array}$ & $\begin{array}{l}0 \\
0 \\
0\end{array}$ & $\begin{array}{l}0 \\
0 \\
0\end{array}$ & $\begin{array}{l}0 \\
0 \\
0\end{array}$ \\
\hline
\end{tabular}

In the 3 control ewes and the 1 testosterone-immunized ewe (No. 443) ovulating regularly, there were no normal follicles $>5.0 \mathrm{~mm}$ diameter. Ewe 397, with irregular ovulation, had 3 non-atretic follicles $>5.0 \mathrm{~mm}$ diameter, with histologically normal granulosa, but the theca cells of these follicles had undergone some degree of differentiation and were enlarged, compact and secretory in appearance (Pl. 1, Fig. 1). The anovulatory ewe (No. 550) had 5 non-atretic

\section{PLATE 1}

Tissues taken from ewes pretreated with exogenous progesterone $(10 \mathrm{mg} /$ day for 12 days). The samples were collected at laparotomy 12 days later (i.e. Day 10 of the oestrous cycle).

Fig. 1. The wall of a Graafian follicle $10 \mathrm{~mm}$ in diameter and showing hypertrophy and hyperplasia of the theca interna, from a ewe immunized against testosterone-3-BSA. $\times 250$.

Fig. 2. Wall of a Graafian follicle $10 \mathrm{~mm}$ in diameter from a control ewe. $\times 250$.

Fig. 3. Modified luteal tissue from a luteinized follicle taken from an ewe immunized against testosterone-3-BSA. $\times 500$.

Fig. 4. Normal luteal tissue from a corpus luteum of a control ewe. $\times 250$. 


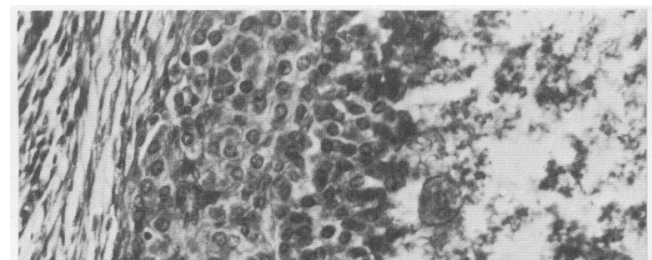

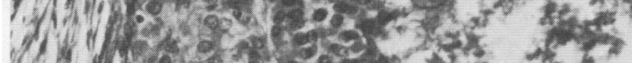

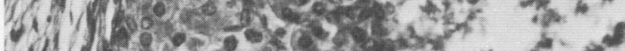

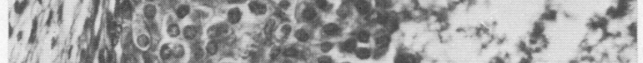

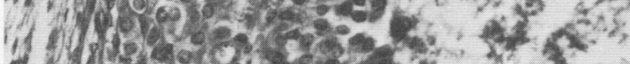

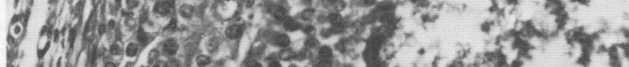

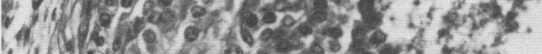

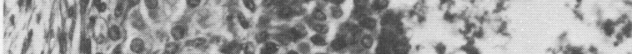

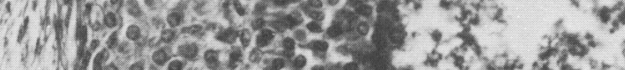
i)

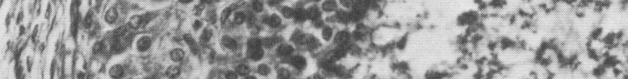

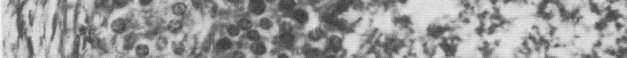

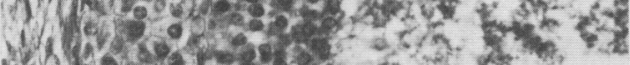

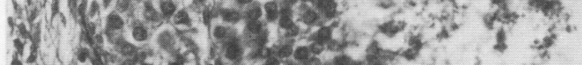

Nind if 1 is

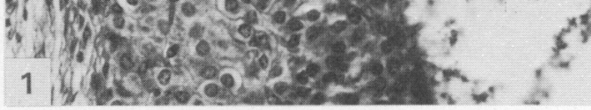

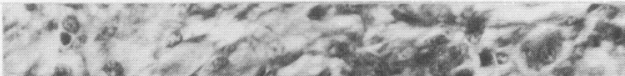

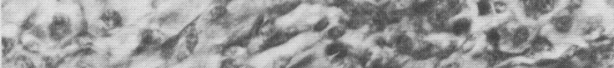

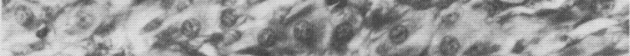

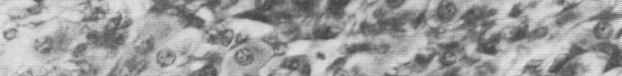

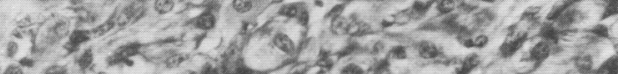

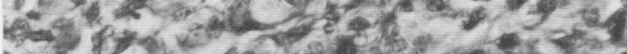

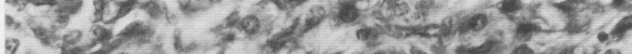

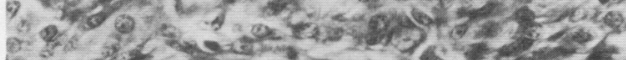

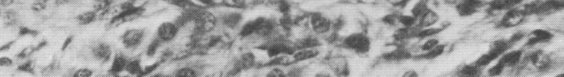

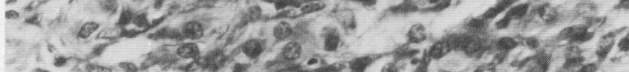

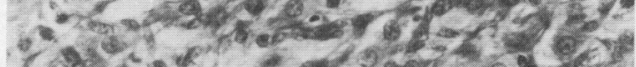

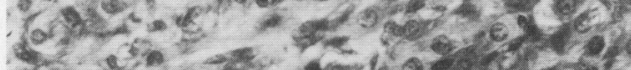

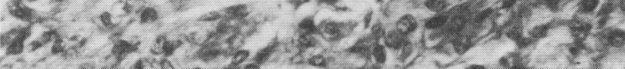

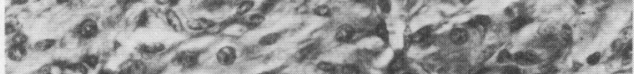

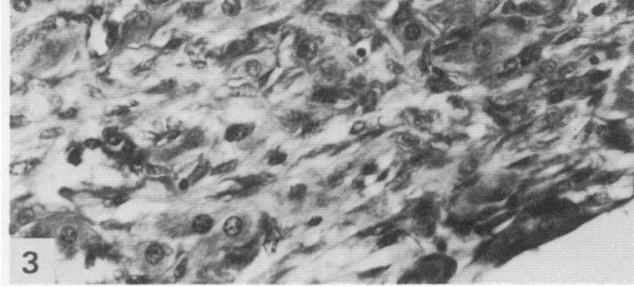

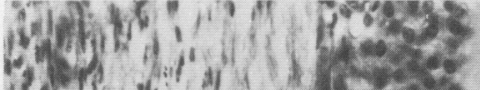

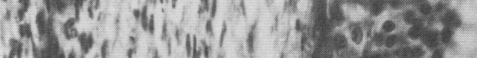
6.

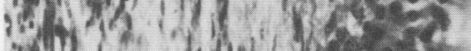

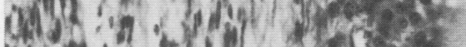

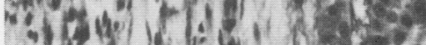

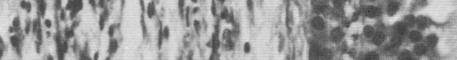

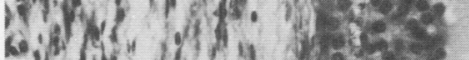

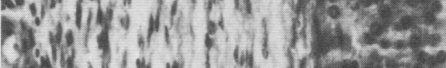

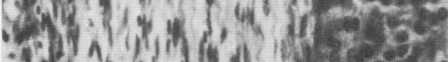

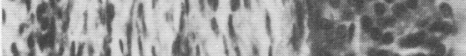

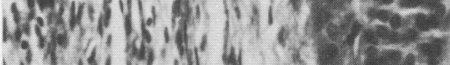

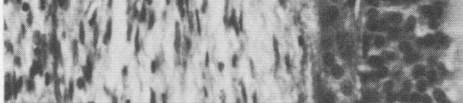

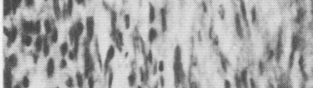

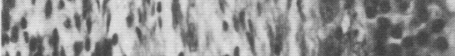

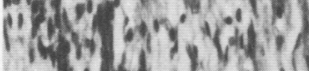
oritas (whing ins

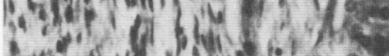

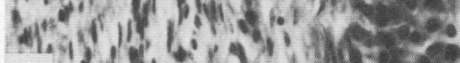

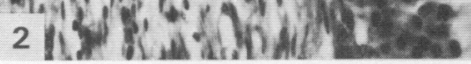

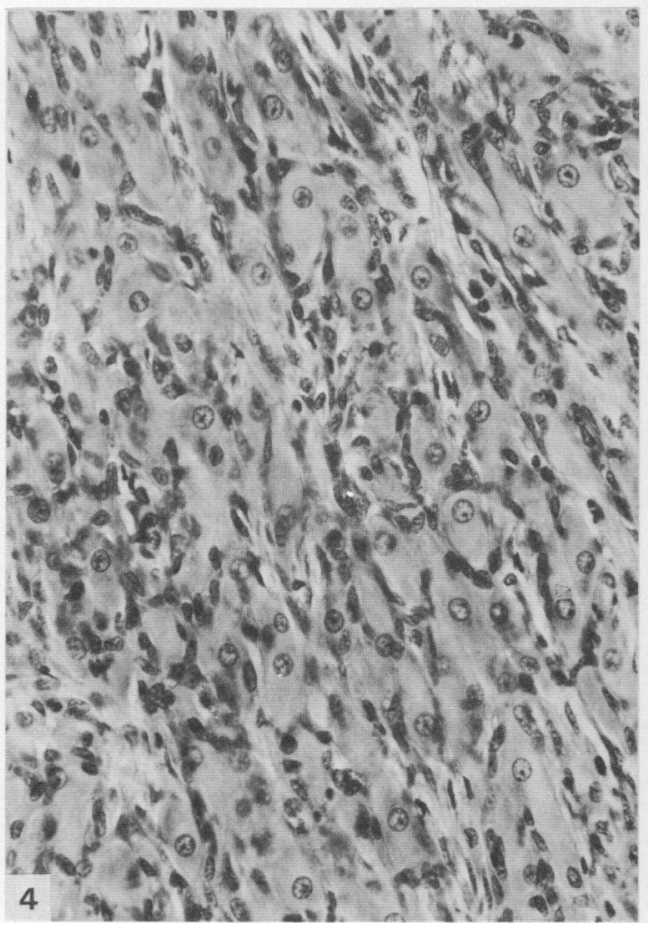


histologically normal follicles $>5.0 \mathrm{~mm}$ diameter, and 6 non-atretic, histologically abnormal follicles (Pl. 1, Figs 1 and 2). These 6 follicles contained modified cells that resembled luteal cells in their staining properties. Unlike true luteal tissue (Pl. 1, Fig. 4), however, the modified tissue was not composed of tightly packed cells organized into lobules by a perilobular reticular network of support cells and fibres (Pl. 1, Fig. 4) but consisted of striated aggregates of luteal-like cells interspersed among numerous, smaller support cells (Pl. 1, Fig. 3). A sizeable antrum was present in 3 of these follicles and an enlarged mass of modified luteal tissue was asymmetrically located at 1 pole of the follicle. In the remaining abnormal follicles the original antrum was reduced to an eccentrically located slit-like lumen.

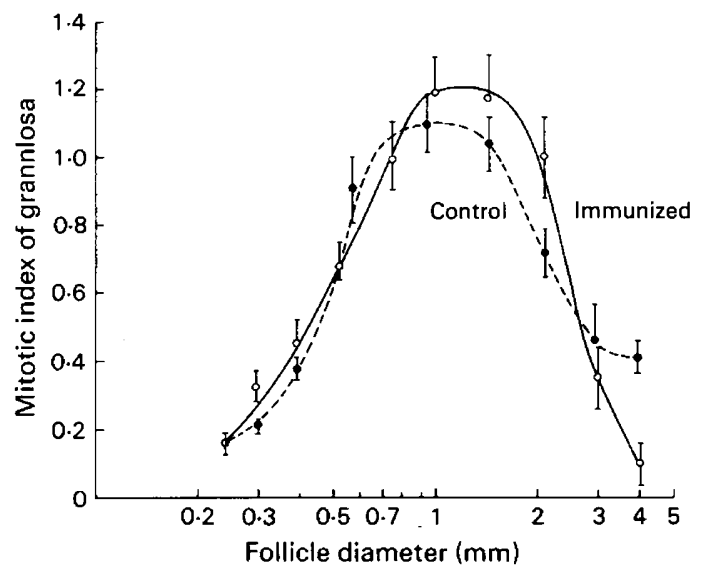

Text-fig. 2. The mitotic index of the granulosa cell layer (mean \pm s.e.m.) as a function of the diameter of Graafian follicles in Welsh Mountain sheep immunized against testosterone-3-BSA (immunized) or BSA (control).

Antibodies. All of the testosterone-immunized ewes produced antibodies capable of binding tritiated testosterone and these antibodies could be readily detected in jugular venous blood (Table 5) and follicular fluid. Follicular fluid at a dilution of $1 / 200$ bound $84.6 \pm 2.3$ (s.e.m.) $\%$ $(n=21)$ of $80 \mathrm{pg}$ tritiated testosterone compared to $85.8 \pm 6 \cdot 2 \%(n=5)$ of a $1 / 200$ dilution of jugular venous plasma. Although the antibody response was directed towards testosterone, antibodies to other steroids were present in lesser quantities (Table 5). This lack of absolute specificity has been confirmed by equilibrium dialysis (Martensz, 1977).

Table 5. The mean (and range) antibody titre (dilution of serum binding $50 \%$ of added radioligand, $\sim 80 \mathrm{pg}$ ) of jugular venous plasma from Welsh Mountain sheep immunized against testosterone-3-BSA or BSA (controls)

\begin{tabular}{lcc}
\hline \multicolumn{3}{c}{ Antibody titre } \\
\cline { 2 - 3 } \multicolumn{1}{c}{ Radioligand } & $\begin{array}{c}\text { Testosterone-3-BSA } \\
(\mathrm{N}=5)\end{array}$ & $\begin{array}{c}\mathrm{BSA} \\
(\mathrm{N}=4)\end{array}$ \\
\hline Oestrone & $1: 6$ & $<1: 1$ \\
Oestradiol-17 & $(1: 1-1: 13)$ & \\
Androstenedione & $(1: 170-1: 950)$ & $<1: 1$ \\
Testosterone & $1: 334$ & $<1: 1$ \\
& $(1: 59-1: 700)$ & $1: 1$ \\
& $1: 21600$ & $(<1: 1-1: 2)$ \\
\hline
\end{tabular}




\section{Discussion}

In an earlier study the secretion rate of testosterone in the intact ewe was reported to be 20-130 $\mathrm{ng} / \mathrm{h} 4$ days after PMSG treatment (Baird et al., 1968). In the present study, the mean secretion rate is similar although the range is wider $(0 \cdot 2-14.2 \mathrm{ng} / \mathrm{min})$. There was no relationship between the secretion of testosterone and androstenedione or oestradiol-17 $\beta$ and in this respect the present results differ from those of Baird et al. (1968).

Immunization against testosterone-3-BSA resulted in excessive ovarian stimulation in most ewes and the degree of over-stimulation appeared to increase with titre (Table 4). Steroid secretion into the ovarian vein and into follicular fluid was greatly increased (Tables 2 and 3 ). These changes are most probably a consequence of the increased levels of LH present in these ewes (Martensz \& Scaramuzzi, 1979). However, it is not clear if the elevated LH levels are the result of neutralization of the biological activity of circulating testosterone or of some other steroid (e.g. oestradiol-17 $\beta$ ) which is also bound by serum from the immunized ewes (Martensz \& Scaramuzzi, 1979).

The ovaries of ewes immunized against testosterone-3-BSA contained many large cystic follicles. The presence of cystic follicles has also been reported in rats (Hillier, Groom, Boyns \& Cameron, 1974) and rabbits (Armstrong, Gauldie \& YoungLai, 1978; Armstrong, McCallion \& YoungLai, 1978) immunized against testosterone-3-BSA. In our sheep, these follicles were steroidogenically active and it seems probable that the atresia which normally acts to eliminate unwanted steroidogenically active follicular tissue had been severely inhibited. The persistence of these large follicles might also be the result of elevated LH levels (Martensz \& Scaramuzzi, 1979) or a direct effect of the removal of biologically active local androgen (Louvet et al., 1975).

It is apparent from Table 4 and Text-fig. 2 that the numbers of developing follicles $0 \cdot 3-3 \cdot 0$ $\mathrm{mm}$ diameter, their growth potential and incidence of atresia in testosterone-immunized ewes are similar to those in control ewes. Ovaries from immunized ewes contained increased numbers of non-atretic follicles 3.0-5.0 mm diameter and normal numbers of non-atretic follicles $>5 \mathrm{~mm}$ in diameter. The retention of significantly more non-atretic, histologically normal follicles $>3 \mathrm{~mm}$ diameter in the immunized ewes could be related to increased longevity as a result of the reduced mitotic index. The increased availability of large, normal, non-atretic follicles can result in increases in ovulation rate (e.g. Ewe 443), as has been reported after immunization against androstenedione (Scaramuzzi, Davidson \& Van Look, 1977).

A high proportion of the ewes immunized against testosterone-3-BSA were anovulatory but the mechanism underlying this ovulatory failure is unclear. The inactivation of biologically active testosterone may have prevented a direct stimulatory effect on ovulation such as occurs in the immature rat (Mori et al., 1977). Alternatively, the presence of antibodies to oestradiol-17 $\beta$ may have interfered with oestrogen induction of the ovulatory LH surge. Ovulation could also be inhibited by the high circulating levels of progesterone produced from the persistent, partly luteinized follicles (Table 2). The initial block of ovulation (whatever its cause) might result in formation of luteinized follicles and further ovulation would not be possible for as long as these follicles persist. These follicles may respond to the luteolytic effects of prostaglandin F-2 $\alpha$ but the abnormal steroid secretion would almost certainly result in impaired synthesis of prostaglandin by the endometrium.

\section{References}

Armstrong, R.W., Gauldie, J. \& YoungLai, E.V. (1978) Effects of active immunization of female rabbits against testosterone. Endocrinology 79, 339-347.

Armstrong, R.W., McCallion, D.J. \& YoungLai, E.V. (1978) Morphological changes in the rabbit ovary after active immunization to testosterone. Cell Tiss. Res. 193, 533-542.
Baird, D.T. (1977) Evidence in vivo for the two-cell hypothesis of oestrogen synthesis by the sheep Graafian follicle. J. Reprod. Fert. 50, 183-185.

Baird, D.T. \& Scaramuzzi, R.J. (1976) The source of ovarian oestradiol and androstenedione in the sheep during the luteal phase. Acta endocr., Copenh. 83, 402-409. 
Baird, D.T., Goding, J.R., Ichikawa, Y. \& McCracken, J.A. (1968) The secretion of steroids from the autotransplanted ovary in the ewe spontaneously and in response to systemic gonadotrophin. J. Endocr. 42, 283-299.

Baird, D.T., Burger, P.E., Heavon-Jones, G.D. \& Scaramuzzi, R.J. (1974) The site of secretion of androstenedione in non-pregnant women. J. Endocr. 63, 201-212.

Baird, D.T., Land, R.B., Scaramuzzi, R.J. \& Wheeler, A.G. (1976a) Functional assessment of the autotransplanted uterus and ovary in the ewe. Proc. $R$. Soc. B. 192, $463-474$.

Baird, D.T., Land, R.B., Scaramuzzi, R.J. \& Wheeler, A.G. (1976b) Endocrine changes associated with luteal regression in the ewe; Secretion of ovarian oestradiol, progesterone and androstenedione and uterine prostaglandin $F_{2 \alpha}$ throughout the oestrous cycle. J. Endocr. 69, 275-286.

Baird, D.T., Swanston, I. \& Scaramuzzi, R.J. (1976c) Pulsatile release of $\mathrm{LH}$ and secretion of ovarian steroids in sheep during the luteal phase of the oestrous cycle. Endocrinology 98, 1490-1496.

Clarke, I.J. \& Scaramuzzi, R.J. (1978) Sexual behaviour and LH secretion in spayed androgenized ewes after a single injection of testosterone or oestradiol-17 $\beta . J$. Reprod. Fert. 52, 313-320.

Corker, C.S. \& Davidson, D.W. (1978) A radioimmunoassay for testosterone in various biological fluids without chromatography. J. Steroid Biochem. 9, 373-374.

Dean, P.D.G., Exley, D. \& Johnson, M.W. (1971) Preparation of 17 $\beta$-oestradiol-6-(O-carboxymethyl)oxime-bovine serum albumen conjugate. Steroids 18 , 593-603.

Hillier, S.G., Groom, G.V., Boyns, A.R. \& Cameron, E.H.D. (1974) Development of polycystic ovaries in rats actively immunized against T-3-BSA. Nature, Lond. 250, 433-434.

Lindsay, D.R. \& Robinson, T.J. (1961) Oestrus-inducing activity of testosterone in the ewe. Nature, Lond. 192, 761-762.

Louvet, J.P., Harman, S.M., Schreiber, J.R. \& Ross, G.T. (1975) Evidence for a role of androgens in follicular maturation. Endocrinology 97, 366-372.

Martensz, N.D. (1977) The experimental manipulation of gonadotrophins in non-pregnant sheep by immunization against steroid hormones. Ph.D. thesis, University of Edinburgh.
Martensz, N.D. \& Scaramuzzi, R.J. (1979) The plasma concentration of luteinizing hormone, folliclestimulating hormone and progesterone during the breeding season in ewes immunized against androstenedione or testosterone. $J$. Endocr. 81, 249259.

McNatty, K.P., Baird, D.T., Bolton, A., Chambers, P., Corker, C.S. \& McLean, H. (1976) Concentration of oestrogens and androgens in human ovarian venous plasma and follicular fluid throughout the menstrual cycle. J. Endocr. 71, 77-85.

Mori, T., Suzuki, A., Nishimura, T. \& Kambegawa, A. (1977) Evidence for androgen participation in induced ovulation in immature rats. Endocrinology 101, 623-626.

Pant, H.C. (1977) Effect of androgens on concentration of $\mathrm{LH}$ and FSH in the peripheral plasma of anoestrous ewes. J. Reprod. Fert. 50, 133-136.

Radford, H.M. \& Wallace, A.L.C. (1971) The effect of testosterone propionate on ovarian activity in sheep. J. Reprod. Fert. 24, 439-440.

Scaramuzzi, R.J. \& Land, R.B. (1978) Oestradiol levels in sheep plasma during the oestrous cycle. J. Reprod. Fert. 53, 167-171.

Scaramuzzi, R.J., Corker, C.S., Young, G. \& Baird, D.T. (1975) Production of antisera to steroid hormones. In Steroid Immunoassay, pp. 111-122. Eds E. H. D. Cameron, S. G. Hillier \& K. Griffiths. Alpha Omega Alpha Publications, Cardiff.

Scaramuzzi, R.J., Davidson, W.G. \& Van Look. P.F.A. (1977) Increasing the ovulation rate of sheep by active immunisation against an ovarian steroid androstenedione. Nature, Lond. 269, 817-818.

Scaramuzzi, R.J., Baird, D.T., Clarke, I.J., Martensz, N.D. \& Van Look, P.F.A. (1980) Ovarian morphology and the concentration of steroids during the oestrous cycle of sheep actively immunized against androstenedione. J. Reprod. Fert. 58, 27-35.

Seamark, R.F., Moor, R.M. \& McIntosh, J.E.A. (1974) Steroid hormone production by sheep ovarian follicles cultured in vitro. J. Reprod. Fert. 41, 143-158.

Turnbull, K.E., Braden, A.W.H. \& Mattner, P.E. (1977) The pattern of follicular growth and atresia in the ovine ovary. Aust. J. biol. Sci. 30, 229-241.

Van Look, P.F.A., Hunter, W.M., Corker, C.S. \& Baird, D.T. (1977) Failure of positive feedback in normal men and subjects with testicular feminization. Clin. Endocr. 7, 353-366. 